\title{
The Effectiveness of Oppemei Model for Enhancing Student's Creative Thinking Skill in Science Basic Concepts Learning
}

\author{
I Gusti Ayu Tri Agustiana \\ Science Education \\ Post Graduate Program \\ State University of Surabaya \\ Indonesia \\ Muslimin Ibrahim \\ Professor, Science Education \\ Post Graduate Program \\ State University of Surabaya \\ Indonesia
}

\author{
Rudiana Agustini \\ Professor, Science Education \\ Post Graduate Program \\ State University of Surabaya \\ Indonesia
}

I Nyoman Tika

Doctor, Elementary Education,

Post Graduate Program

State University of Education Ganesha, Indonesia.

\begin{abstract}
This study was conducted to find out the effectiveness of OPPEMEI model for enhancing student's creative thinking skill. This study was started by developing science basic concepts teaching material for the topics of Material Change by using the 4-D model. The subjects were the third semester students of Elementary Education Department of the Faculty of Education Science, Universitas Pendidikan Ganesha, Singaraja, Bali, Indonesia with the total number of 117 students divided into four classes: Classes $\mathrm{A}, \mathrm{B}, \mathrm{C}$ and F. The results showed that the validity of the teaching material falls into the vary valid category. OPPEMEI model is effective for enhancing student's creative thinking skill with the first cycle gain score in the low category for Class $\mathrm{F}$, the second cycle in the medium category for Class $C$, the third cycle in the medium category for Class $B$ and the fourth cycle in the high category for Class A. There is a significant difference between the pre-test score and the post-test score for the four classes based on the t-test analysis (N-Gain score). There were some changes in the students' creative thinking skill from medium to high category in the indicators of fluency, flexibility, elaboration, and evaluation, while the indicator of originality was in the medium category.
\end{abstract}

Keywords:- OPPEMEI Learning Model, Elementary School Prospective Teachers' Creative Thinking Skill, Science Basic Concepts.

\section{INTRODUCTION}

Students' creative thinking skill has become an interesting topic in the last few years in Indonesia. This has been based on the fact that university students' creativity, especially in science, is still relatively low compared to that in other countries, especially that of the elementary school prospective teachers who are the spearheads in introducing science at the first level [1].Some improvements have been made in the infrastructure, facilities and teaching process by implementing various teaching models that are appropriate for basic science teaching [2].

Appropriate teaching models are those that suit the spirit of the $21^{\text {st }}$ teaching model with its four characteristics :(1) critical thinking and problem solving, (2) creativity and innovation, (3) communication, and (4) collaboration. One of the characteristics that needs to be developed is creativity and innovation in the students. Students with this characteristic have the ability to develop, implement, and communicate new ideas to others, have an open attitude and are responsive to new and different perspectives [3].

The creativity and innovation ability can develop well if the teaching is done by a professional, creative and open minded teacher[4]. Consequently, there is an urgency for having teachers who open the opportunity as widely as possible for the students to develop their creative thinking skill. Creative thinking skill is one of the abilities of an individual to find a different strategy, or a new method to be able to produce something different [5]

Creativity is shown by a creative ability or the ability to produce something "new". Munandar defines creativity as the possession of an ability to produce something new, and innovativeness is supported by the ability to renew something that has existed before [6]. In addition, according to Beetlestone, creativity is an important element in social life, thus it needs to be developed in the teaching process [7].

Hence creativity can be developed early in life, so the students of elementary education need a training in creativity as to be able to understand abstract ideas optimally, especially for mathematics and science teaching in such a way that the subjects can be understood easily by elementary school students. The teaching of creativity for the students makes it the development of responsibility for individual learning possible [8]. 
Hence, the teaching method used by the lecturers need to be modified by inserting elements that can enhance creativity of the prospective elementary school teachers. This condition shows the need for a more intensive guidance by a lecturer to ensure the students's success [9].

Creative thinking ability of the students in science teaching continues to be encouraged. Science teachers' skill should be developed earlier when they are still studying as the students at elementary school education department. Hence, various efforts have been made in science teaching to develop creative thinking skill by class video project model. This method can enhance creativity significantly in the students of elementary school education [10].

The students need to be prepared to face the quickly changing future. Thus the science teaching model needs to be given to the students optimally. Another strategy that has been implemented for enhancing creativity is by providing meanings in the students' life by using the Inquiry Based Science model (IBSE) [11].

However, all of these are not yet maximum for enhancing creative thinking ability of the elementary school prospective teachers. Hence, the implementation of a new model for enhancing creative thinking skill is interesting to explore.

A teaching model development was started by focusing the improvements on the weaknesses of three types of teaching model that are often used in science teaching: problem based learning (PBL), inquiry and brain based learning (BBL), which was produced by following stage (1) orientation, (2) exploration of creative ideas investigation, (4) elaboration, (5) exhibition of works, (6) evaluation as reflection and revision, and the last stage (7) implementation. This model was called OPPEMEI with 7 syntaxes [12].

Empirically, science teaching was done by some researchers to enhance creativity of the students of elementary school teachers education. Fazilla found that the students of elementary school who were given science student's work sheet could easily read and understand the messages contained in the student's worksheet with a high implementation and judgment levels, and the science teaching was effective if the meaning and use of it was understood correctly [13].

In addition, the characteristics of OPPEMEI model cover: (a) flexibility that can be achieved by giving a structured orientation to the students in such a way that it stimulates their brain performances to be able to do association thinking to produce new ideas that become the product of creative tinking; (b) newness of ideas. The students' thinking ability needs the room for exploring new ideas. New ideas can occur if a problem is given that produces a cognitive conflict condition in the students; (c) after obtaining ideas, the testing of the ideas needs to be done to obtain data by doing an investigation; (d) the appearance of new ideas, that are resulted from creative thinking which needs a condition that makes it possible for the students to process inputs of ideas from various sources. This condition needs an elaboration phase in the teaching stage; (e) the result of the investigation needs a stage for presenting works; (f) the ideas that are presented need to be evaluated to get feedbacks for strengthening ideas that are produced from the creative thinking process; and (g) inputs that are obtained needs reinforcement, thus it needs integration to be implemented to make an internalization process occur in the students [12].

Thus, there is a need for an in-depth study of the effect of the implementation of the OPPEMEI teaching model on the creative thinking skill of the students of Elementary School Teachers Education Department of Universitas Pendidikan Ganesha for the science basic concepts course in the topic of material change.

\section{MATERIAL AND METHODS}

This study belonged to research and development using a pretest post-test design [14]. The implementation of the study followed the following steps: First, developing teaching material for the topic of material change that refers to the 4-D model [15].

There are four types of teaching material developed based on the OPPEMEI model: unit of lecture program unit (SAP), student's textbook, student's work sheet, and creative thinking skill test. Secondly, validating all the materials by experts and teachers before they were implemented in the teaching of science before being implemented in teaching science basic concepts.

Third, the implementation of the study was done in the Elementary School Teachers Education Department of Universitas Pendidikan Ganesha Singaraja Bali, Indonesia, in the academic year 2018/2019. The subjects consisted of 117 students of the third semester who were divided into 4 classes (Classes A (28 students), B (28 students), C (29 students) and F (31 students ).

Fourth, the teaching process was conducted for 4 meetings with the subtopics: (1) Physical and Chemical Changes, (2) Mixed Change, (3) Acid, base and salt properties and (4) applications of acid and base properties on corrosion. The data were collected by using 3 instruments: test validation sheet, test and questionnaire.

\section{RESULT AND DISCUSSION}

\section{A. Teaching Materials Validation}

After writing the teaching materials, the teaching materials were validated. There were four types of teaching materials developed: lecture unit, student's textbook, student's work sheet and creative thinking test The validation of the teaching materials were done by three experts. The results of the validation are presented in Table 1. 


\begin{tabular}{|c|c|c|c|c|}
\hline \multirow{2}{*}{$\begin{array}{l}\text { Teaching } \\
\text { Materials }\end{array}$} & \multicolumn{2}{|c|}{ Validity } & \multicolumn{2}{|c|}{ Reliability } \\
\hline & Score & Remark & $\begin{array}{l}\mathbf{R} \\
(\%)\end{array}$ & Remark \\
\hline Lecture unit & 4.8 & Very valid & 95 & reliable \\
\hline $\begin{array}{c}\text { Student } \\
\text { textbook }\end{array}$ & 4.9 & Very valid & 98 & reliable \\
\hline $\begin{array}{c}\text { Student's } \\
\text { Work Sheet }\end{array}$ & 4.8 & Very valid & 93 & reliable \\
\hline $\begin{array}{c}\text { Creative } \\
\text { Thinking Skill } \\
\text { Test }\end{array}$ & 4.3 & Very valid & 94 & reliable \\
\hline
\end{tabular}

Table 1:- Results of Validation of Teaching Materials

The result of the teaching validation can be seen as in table 1/ All of the types of the teaching materials developed in this study have the very valid category. Lecture unit has met the validity criterion. The result of teaching has been adapted to the competence indicator required by the curriculum of the Elementary School Teachers Education Department. The design of the teaching was made in a complete form systematically so that the teaching process could run in an interactive, inspirative, joyful, challenging, efficient way to motivate the students to play an active role in the teaching process.

The result of the expert's validation shows that the student's work sheet is feasible to be used as a medium of interaction in the teaching of science basic concepts. Problems were given by the lecturer and the students were helped with student's work sheet in solving problems related to the OPPEMEI teaching model. With the presence of the student's work sheet the students could learn and work together to help each other and understand the course well so that it made it possible for them to learn other people's ways to solve problems [16].

The presence of the student's work sheet was the realization of the constructivist theory, in which the student's work sheet could be written and designed to make students learn easily through practices, information and evaluation. Then the students were given the opportunity to correlate the topic of material change to the phenomena in daily life, analyze the result of the observation and discuss them so that the students could understand the concepts that they learned. [17]

\section{B. Student's Creative Thinking Skill}

Creative thinking skill is the process of thinking for developing or finding ideas or original, aesthetic, constructive works that are related to the perspective and concept that stress the importance of intuitive and rational thinking especially in using information and materials to develop or explain them using an original thinker's perspective. According to Munandar [6] the qualities that characterize creative thinking characteristics are fluency, flexibility, originality, elaboration, and evaluation. The following are the results of the students' creative thinking skill from the four classes.

\begin{tabular}{|c|c|c|c|c|c|}
\hline Indicator & Result & Class F & Class C & Class B & Class A \\
\hline \multirow{4}{*}{ Fluency } & P1 & 0.74 & 1.11 & 1.23 & 1.54 \\
\hline & P2 & 1.42 & 1.63 & 1.81 & 2.38 \\
\hline & N-gain & 0.39 & 0.57 & 0.86 & 0.90 \\
\hline & Remark & medium & medium & high & high \\
\hline \multirow{4}{*}{ Flexiblity } & P1 & 0.43 & 0.57 & 0.58 & 0.64 \\
\hline & P2 & 0.79 & 0.92 & 1.14 & 1.97 \\
\hline & N-gain & 0.22 & 0.34 & 0.52 & 0.98 \\
\hline & Remark & low & medium & medium & high \\
\hline \multirow{4}{*}{ Original } & P1 & 0.06 & 0.16 & 0.19 & 0.29 \\
\hline & P2 & 0.24 & 0.60 & 0.62 & 1.17 \\
\hline & $\mathrm{N}$-gain & 0.20 & 0.27 & 0.30 & 0.50 \\
\hline & Remark & low & low & medium & medium \\
\hline \multirow{4}{*}{ Elaboration } & P1 & 0.70 & 0.94 & 0.58 & 0.99 \\
\hline & P2 & 1.20 & 1.67 & 1.81 & 1.91 \\
\hline & N-gain & 0.36 & 0.54 & 0.68 & 0.69 \\
\hline & Remark & medium & medium & medium & high \\
\hline \multirow{4}{*}{ Evaluation } & P1 & 0.32 & 0.39 & 0.54 & 0.74 \\
\hline & P2 & 0.79 & 1.28 & 1.54 & 2.07 \\
\hline & N-gain & 0.27 & 0.55 & 0.67 & 0.74 \\
\hline & Remark & low & medium & medium & high \\
\hline
\end{tabular}

Notes: P1 = the Pre Test Score for Creative Thinking Skill

P2 = the Post-test Score for Creative Thinking Skill

Table 2:- Recap of N-gain for creative thinking skill in the trial stage 


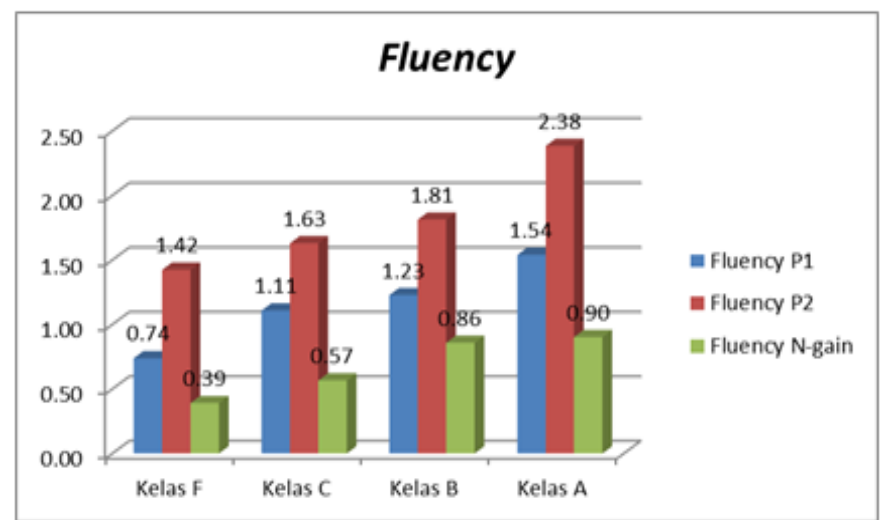

Fig 1:- Comparison of the results of creative thinking scores in the indicator of fluency among Classes F, C, B and $\mathrm{A}$

There was an increase in creative thinking skill in the trial stage in the indicator of fluency. The N-Gain scores were 0.39 (medium) for Class F; 0.57 (medium) for Class C; 0.86 (high) for Class B; and 0.90 (high) for Class A. Classses B and A got high scores for the indicator of fluency.

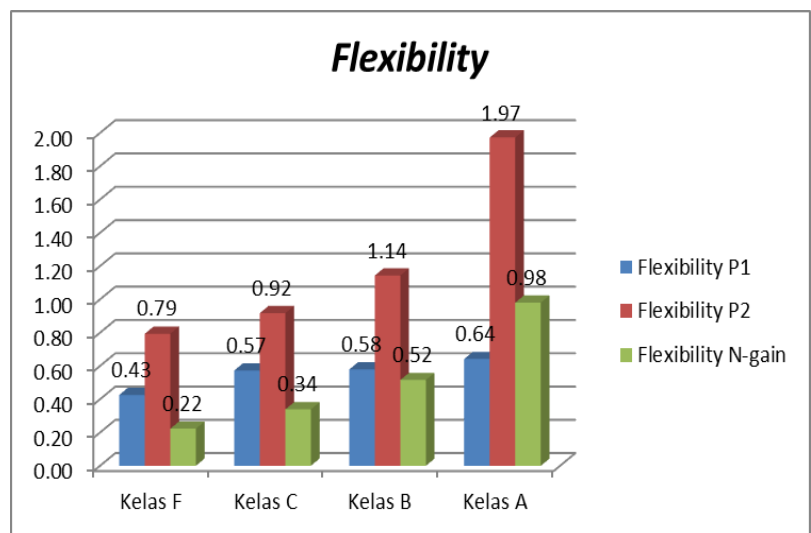

Fig 2:- Comparison of the results of creative thinking skill test in the indicator of flexibility among Classes F, C,B,and

A

The N-Gain scores in the indicator of flexibility were 0.22 (low) for Class F; 0.34 (medium) for Class C; 0.52 (medium) for Class B; and 0.98 (high) for Class A. In the indicator of flexibility only Class A got a high score.

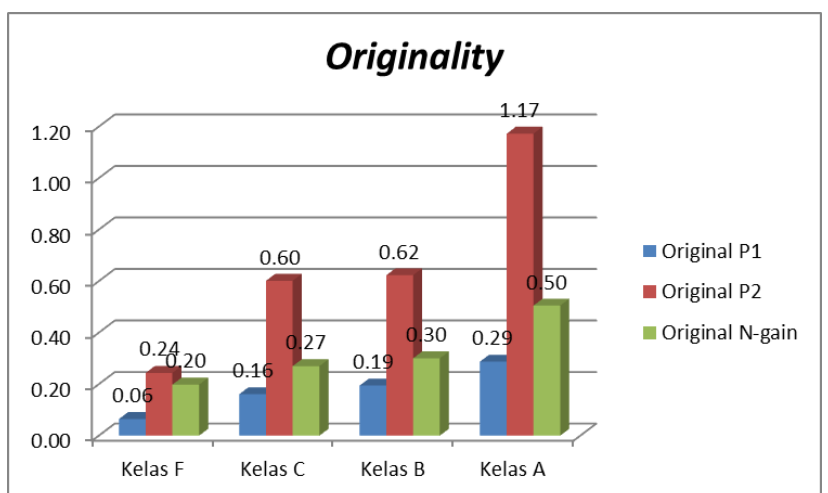

Fig 3:- Comparison of the results of creative thinking skill in the indicator of originality among Classes F, C, B, and A
The N-Gain scores in the indicator of originality were 0.20 (low); 0.27 (low); 0.30 (medium); and 0.50 (medium). In the indicator of originality no classes that got a high increase in creative thinking skill. They only got scores that fall into low to medium category.

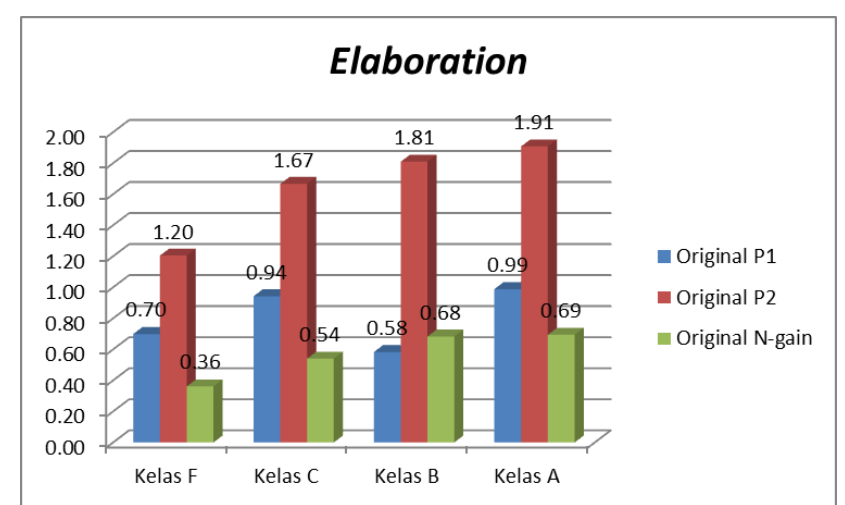

Fig 4:- Comparison of the results of creative thinking skill in the indicator of elaboration among Classes F, C, B, dan A

The N-Gain Scores in the indicator of elaboration were 0.36 (medium); 0.54 (medium); 0.68 (medium); and 0.69 (high). In the indicator of elaboration only Class A got a high score.

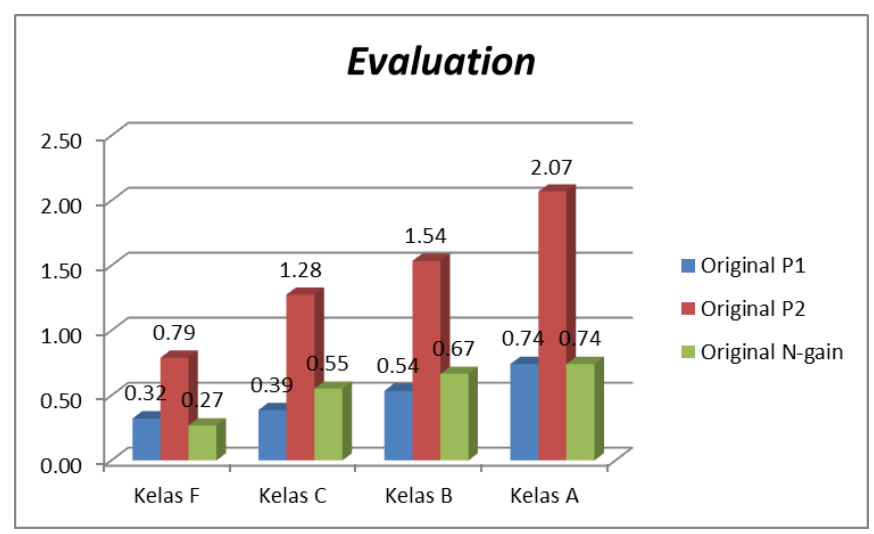

Fig 5:- Comparison of the test results in creative thinking skill in the indicator of evaluation among Classes F, C, B, and $\mathrm{A}$

Based on the graph above the N-Gain scores in the indicator of evaluation were 0.27 (low); 0.55 (medium); 0.67 (medium); and 0.74 (high). In the indicator of evaluation Class A got a high score, it is seen clearly that the post-test result in creative thinking test significantly increased in the indicator of evaluation. It can be concluded that the students' creative thinking skill can be improved by implementing the OPPEMEI model in science basic concepts teaching. The students' creative thinking skill increased and this could occur due to their curiosity that was developed by implementing the OPPEMEI model. The thinking creativity motivated the students' curiosity. This finding proves that the students actually had a high intelligence since their intelligence and spirit, their curiosity, clarity and sharpness of their visions made the learning joyful and dynamic [18]. 
The teaching actually focused on the effort to increase curiosity. Every individual has a different quality of curiosity Some consider it important and others consider it a normal attitude. Curiosity is an individual's need to get answers to things that require deep curiosity which can develop creative thinking skill [19].

Students can develop intrinsic motivation and self confidence through an appropriate implementation of the OPPEMEI model in which they are given orientation and conditioned through a creative ideas exploration approach. A continuous cyclic process produces motivation to internalize values. There is a strength that can motivate efforts to do something from within an individual due to his or her hobby.

The OPPEMEI model makes it possible to define in details the way that students follow in which social role, group norms, interpersonal relation and institution's structural obstacles can develop experience, motivation and group endurance in the students who are underrepresented through the processes of elaboration and work presentation, that form the activities of each group [12].

The creative thinking skill that was used during the implementation of the teaching as shown in the OPPEMEI model phases is very relevant to the dual coding theory that has an implication in the positive response of the students. The students responded that the teaching that engaged the use of the OPPEMEI model is interesting and provides them with new experience [12]. This condition is in line with the teaching models with various challenges which make them able to meet real challenges, this condition is very suitable for the skills that are required by the $21^{\text {th }}$ century teaching with the goal of preparing children to face the more complex and quickly changing world. [20].

\section{CONCLUSION}

The OPPEMEI model is very effective for enhancing students' creative thinking skill. The results of the study showed that the scores obtained in Cycle I fall into the low category for Class F, in cycle II fall into the medium category for Class $\mathrm{C}$, in cycle II into the medium category for Class B and in cycle IV into the high category for Class A. There is a significant difference between the pretest scores and the post-test scores for the four classes based on the N-Gain scores analysis. The students' creative skill changed from low, medium to high in the indicators of fluency, flexibility, elaboration, and evaluation while in the indicator of originality was in the medium category.

\section{REFERENCES}

[1]. Agustiana. T. I G.A. Model Pembelajaran OPEMEI dalam meningkatkan Keterampilan Berpikir Kreatif Mahasiswa PGSD. Makalah. Diselenggarakan Program Studi Pendidikan Sains Program Pascasarjana Universitas Negeri Surabaya. Surabaya: Prosiding Seminar Nasional Pendidikan Sains. ISBN: 978-602-72071-0-3. Pp`. 1423-1433. 2015

[2]. Agustiana. T. I G.A. Agustini, Rudiana., Ibrahim Muslimin. Effect of brain based learning model on ability of concepts and creative thinking skills for students base on ability of science for students of department elementary school of education. Paper. The 1st International Conference on Innovative Research Across Disciplines (ICIRAD). Denpasar: Prosiding Seminar Internasional Undiksha. ISBN: 978-602-1213-89-6. pp. 98-108. 2015.

[3]. Sutoyo, S., Azizah, U., \& Allamin, S. Effectiveness of the Guided Inquiry Model Integrated with STEM to Improve the Student Critical Thinking Skills in Chemistry Learning. International Journal of Innovative Science and Research Technology. Volume 4, Issue 12, December - 2019

[4]. Fransiska, H., Leny, Y., \& Muslimin, I. Validity of the CDR-Po Learning Model to Develop Students' Creative Thinking Skills in Middle School Science Learning. International Journal of Innovative Science and Research Technology. Volume 4, Issue 5, May2019.

[5]. Moreno, R. Educational Psychology. University of New Mexico: John Wiley \& Sons, Inc. 2010

[6]. Munandar, Utami. Pengembangan Kreativitas Anak Berbakat. Jakarta: PT Gramedia Utama 2009

[7]. Beetlestone, F. Creative Learning: Imaginative Teaching. 2012.

[8]. Suwandari, S., Ibrahim, M., \& Widodo, W. Application of Discovery Learning to Train the Creative Thinking Skills of Elementary School Student.2019. International Journal of Innovative Science and Research Technology. Volume 4, Issue 12, December - 2019

[9]. Ferrari A., Cachia R., \& Punie Y. ICT as a Driver for Creative Learning and Innovative Teaching . 2009.

[10]. Dewi, H. R., Mayasari, T., \& Handhika, J. Increasing Creative Thinking Skills And Understanding Of Physics Concepts Through Application Of StemBased Inquiry. Jurnal Penelitian Pendidikan IPA, 4(1), 25-30. 2019.

[11]. Riga, F., Winterbottom, M., Harris, E., \& Newby, L. Inquiry-based science education. In Science education (pp. 247-261). Brill Sense. 2017

[12]. Agustiana Tri, I G.A., Rudiana Agustini, Muslimin Ibrahim, I Nyoman Tika. Perangkat Pembelajaran (RPS dan SAP) IPA Model (OPPEMEI) untuk Meningkatkan Keterampilan Berpikir Kreatif Mahasiswa PGSD. Jurnal Ilmiah Sekolah Dasar. Volume 4, Number 2, 2020 pp. 176-186. P-ISSN: 2579-3276 E-ISSN : 2549-6174 ttps://ejournal.undiksha.ac.id/index.php/JISD/index. 2020. 
[13]. Fazilla, S. Pengembangan Kemampuan Afektif Mahasiswa Pgsd Dengan Menggunakan Bahan Ajar Lembar Kerja Mahasiswa (LKM) dalam Pembelajaran IPA Di Universitas Almuslim. Jurnal Pendidikan Dasar (JUPENDAS), 1(2). 2016.

[14]. Park, J., \& Park, M. Qualitative versus quantitative research methods: Discovery or justification? Journal of Marketing Thought, 3(1), 1-8. 2016.

[15]. Thiagarajan, S. Instructional development for training teachers of exceptional children: A sourcebook.1974.

[16]. Slavin, R.E. Educational Psycology: Theory and Practice: 8th Edition. Boston: Alyn and Bacon. 2012

[17]. Hergenhahn, B.R. \& Olson, M.H., Theories of Learning. New York: Psychology Press, 2016.

[18]. Wade, S., \& Kidd, C. . The role of prior knowledge and curiosity in learning. Psychonomic bulletin \& review, 26(4), 1377-1387. 2019

[19]. Lamnina, M., \& Chase, C. C. Developing a thirst for knowledge: How uncertainty in the classroom influences curiosity, affect, learning, and transfer. Contemporary Educational Psychology, 59, 101785. 2019.

[20]. Gu, X., Dijksterhuis, A., \& Ritter, S. M.. Fostering children's creative thinking skills with the 5-I training program. Thinking Skills and Creativity, 32, 92-101. 2019 